\title{
The Perspectives of Russia's Soft Power in the Western Balkans Region
}

\author{
A. Djokic \\ Peoples' Friendship University of Russia (RUDN University) \\ 6 Miklukho-Maklaya St, Moscow, 117198, Russian Federation \\ dzhokich_a@pfur.ru

\section{Перспективы мягкой силы России в регионе Западных Балкан}

\author{
А. Джокич \\ Российский университет дружбы народов \\ Российская Федерациия, 117198, Москва, ул. Миклухо-Маклая, 6 \\ dzhokich_a@pfur.ru
}

\begin{abstract}
The article analyzes the perspectives of Russia's soft power in the Balkans. The Russian Federation has longstanding historical, political, cultural and economic ties to the Balkan region. Therefore, being free of a one-sided ideological approach that hampered the usage of soft power by the USSR during the Cold War era, Russia stands at the crossroads as to how best to use it's great potential for peaceful diplomacy and influence in the Western Balkans. The article will provide an analysis of the achievements of the Russian Federation in regards to extending it's influence in the Western Balkans, but also the downsides of it's foreign policy. The analysis will encompass several Western Balkan states and their ties to Russia in terms of soft power: Serbia, Montenegro and Bosnia and Herzegovina. The article raises the question: whether Russia can withstand the struggle for influence over the Balkans with it's greatest rivals in the region - the United States and the EU? The author concludes that it depends largely on the various approaches and methods used by Russian diplomacy and the level of funding of various projects that can be used to extend Russia's cultural influence in the Balkan peninsula.
\end{abstract}

Keywords: Russia, Balkans, soft power, influence, diplomacy, cooperation

Article history: Submitted on 29.01.2020. Accepted on 01.03.2020.

For citation: Djokic A. The Perspectives of Russia's Soft Power in the Western Balkans Region. RUDN Journal of Political Science. 2020; 22 (2): 231-244. DOI: 10.22363/2313-1438-2020-22-2231-244

(C) Djokic A., 2020.

(c) (i) This work is licensed under a Creative Commons Attribution 4.0 International License https://creativecommons.org/licenses/by/4.0/ 
Аннотация. В статье анализируются перспективы мягкой силы России на Балканах. Российская Федерация имеет давние исторические, политические, культурные и экономические связи с Балканским регионом. Поэтому, будучи свободной от одностороннего идеологического подхода, который препятствовал использованию мягкой силы СССР в эпоху холодной войны, Россия стоит перед выбором относительно того, как наилучшим образом использовать свой огромный потенциал для мирной дипломатии и влияния на Западных Балканах. В статье будет проведен анализ достижений Российской Федерации в области расширения ее влияния на Западных Балканах, а также недостатков ее внешней политики. Анализ будет охватывать несколько государств Западных Балкан и их связи с Россией с точки зрения мягкой силы: Сербию, Черногорию и Боснию и Герцеговину. В статье поднимается вопрос: сможет ли Россия выстоять в борьбе за влияние на Балканах с ее главными соперниками в регионе - США и ЕС? Автор приходит к выводу, что во многом это зависит от различных подходов и методов, используемых российской дипломатией, и уровня финансирования проектов, которые могут быть использованы для расширения культурного влияния России на Балканском полуострове.

Ключевые слова: Россия, Балканы, мягкая сила, влияние, дипломатия, сотрудничество

История статьи: Поступила в редакцию 29.01.2020. Принята к публикации 01.03.2020.

Для цитирования: Djokic A. The Perspectives of Russia's Soft Power in the Western Balkans Region // Вестник Российского университета дружбы народов. Серия: Политология. 2020. T. 22. № 2. C. 231-244. DOI: 10.22363/2313-1438-2020-22-2-231-244

\section{Introduction}

In order to properly present the research and analysis in the article, it is necessary to provide the theoretical structure on which this work is based upon. That means that the various, often conflicting, definitions of soft power must be presented and taken into account. Furthermore, it is necessary to establish a time framework of the article, it's scope and goals. Next, the introductory part of the article will provide the general analysis of Russia's potential in the field of soft power in the Western Balkans region, but also the pitfalls and negative sides of Russia's image among the Balkan nations. Thus, the introduction will consist of three parts: 1. the theoretical part, 2. the defining part, 3. the general analysis of the problem.

Whenever we read an article, research paper, analysis or a book containing the term soft-power we are always referred to globally famous American researcher Joseph S. Nye, who coined the term. While his later works deal mostly with the problems of how to better implement and use soft power as a means of reaching some state's political or economic goals, his earlier works provide the theoretical framework of said term. In his book Soft Power - The Means to Success in World Politics [1] Nye defined soft power as an "indirect way to get what you want". Nye further added that soft power is "getting others to want the outcomes that you want" and "the ability to shape the preferences of others". This almost benign view of the nature of power, which Nye's definitions imply, has often been challenged in theoretical disputes. These criticisms have their root mostly in the Gramscian early structuralist critique of "cultural hegemony" and classical elite theory of Pareto, 
Mosca and Michels. Most authors summarize this view of soft power, as a means of manipulation and coercion, as the third face of power [2].

In this discourse there are two broad philosophical schools of thought that have formed over the past decades in the discussion about the nature of power in politics and international relations. On one hand are mostly Anglo-American scholars who view power as an instrument to be used in order to achieve set goals. Both the neorealist and the neoliberal approaches share this utilitarian view of power, even if they see the goals of the usage of power in different ways [3]. On the other side of the spectrum we find neo-Marxist structuralists inclined to present power as the means to dominate, rather than simply influence. Their theories always evolve around the centers of power, formal or informal, that project power over less developed countries, or disparaged classes within those countries. Thus, neo-Marxists evolved from state-centric views to market and class-centric ones. The modern poststructuralists [4] added an interesting argument in this debate, arguing that there mustn't always be a center of power projection, that many pieces of the dominant cultural discourse are not spread by state or private actors, but rather by the individual himself. Philosophically speaking this is the most interesting concept of the Information age, as it decentralizes the spread of power and puts emphasis on the individual rather than the faceless state or suprastate institutions, or market and class constructs [5].

As this article is about Russia's concept the author will however use the neorealist paradigm of power as a means to an end, whether it is used by national or international institutions. This approach fits best with Russia's concept of foreign policy and it's actions in practice. This is also visible from the actual Foreign Policy Concept of the Russian Federation written in 2016: "Alongside military might, other important factors allowing States to influence international politics are taking center stage, including economic, legal, technological and IT capabilities. Using these capabilities to pursue geopolitical interests is detrimental to efforts to find ways to settle disputes and resolve the existing international issues by peaceful means on the basis of the norms of international law. In addition to traditional methods of diplomacy, 'soft power' has become an integral part of efforts to achieve foreign policy objectives. This primarily includes the tools offered by civil society, as well as various methods and technologies - from information and communication, to humanitarian and other types" 2 . The strategy of Russian Federation clearly accepts the state to be an actor of spreading soft power, alongside with civil society and corporate actors (information and media can also be privately owned).

The time framework of this article stretches from 1992, after the breakup of the Soviet Union and the start of independent foreign policy of modern Russia, up

\footnotetext{
${ }^{2}$ Foreign Policy Concept of the Russian Federation (approved by President of the Russian Federation Vladimir Putin on November 30, 2016). URL: https://www.mid.ru/en/foreign_policy/ official_documents/-/asset_publisher/CptICkB6BZ29/content/id/2542248 (accessed: 27.02.2020).
} 
to the current year - 2020. The article aims to present the data and conclusions about Russia's soft power in the Western Balkans, and it's perspectives for further growth. The main aspects of soft power wielded by Russia presented in this article will be: 1. historical ties, 2. cultural ties (language, religion, education), 3. the media and communications aspect, 4. economic ties. The Western Balkan countries involved in this research article will be: Serbia, Montenegro and Bosnia and Herzegovina.

Russia and the various Balkan nations and nation-states have longstanding relations predating the formation of the European Union and even the United States of America. This has both positive and negative consequences. The positive ones stem from the fact that Balkan nations accept as a given the fact that Russia is a major stakeholder in the region, while the EU and the US are seen as relative newcomers (of course the EU consists of various influential countries that also had dealings or even governed the Balkans in the past, such as Germany, Austria and Italy). The negative consequences are rooted in the fact that Russia has through history intervened and waged wars in the Balkans which in practice means it took sides of some nations against the others. Since many animosities are still vivid in the collective memories of the Balkan nations, such transgressions are not easily forgotten, if at all. The other negative aspect is the burden of communist heritage that Russia is forced to carry and this is often used as a quite successful instrument of propaganda by the Western officials and media active in the Balkans. The countries that were once a part of the so-called Soviet Bloc - Romania, Bulgaria and Albania, are mostly affected by this.

In recent years, especially after the start of the Ukrainian crisis in 2014, Russia has started to once again extend it's dormant influence in the Balkans. Many analytical articles have been written on the subject, mainly from a negative point of view e.g. Russia tries to subvert the Western Balkans region by blocking the ascension of Balkan states to NATO, or similarly, Russia tries to bribe local Balkan elites to change their policies [6]. Many Russian authors have also written on this topic, albeit in Russian, thus not engaging in debate with their Western colleagues. However, the question stands whether an objective debate on issues of foreign policy is even possible, considering the intensity of conflict in the current structure of international relations. The goal of this article is not to criticize or praise Russian involvement in the Western Balkans but rather to measure it and try to present advice.

\section{Perspectives of Russia's soft power in Serbia}

Serbia and Russia are thought to be longstanding allies and partners. Their historical ties stretch back to the early Middle Ages, when both the Serbian and Russian nations adopted Orthodox Christianity as their religion. Cultural exchange between medieval Serbia and Russia was very developed up to the 15 th 
century, when Serbia was conquered by the Ottoman Turks. Up to this point, Serbia mainly influenced Russia, and not the other way around, owning it's cultural influence to the proximity of the then most developed country in Europe - the Byzantine Empire. After this period, however, Russia became the dominant political and cultural force amongst the Orthodox Christian world and it's influence started to spread to the Balkans, including Serbia. This is highly noticeable beginning from the 18th century, reaching it's height in the early 20th century which saw the breakout of the First World War.

In Serbian historical literature and political discourse, the definition of Serbs as "little Russians" from the Western point of view is predominant [7]. This term appeared in British diplomacy in the second half of the 19th century and has since then found a firm footing in Serbian political discourse. This term implies, that no matter what, the Western countries will always regard Serbs as actors of influence on behalf of Russia. This sort of deterministic thinking is obviously flawed, but nonetheless it emphasizes Russia's predominant role in the collective mindset of the Serbian nation. This bodes well for Russia's soft power, as it is far more easily spread than that of the United States and the EU. Russia's diplomatic aid in the political struggle for Serbia to retain the control of the semi-independent province of Kosovo is surely one of the greatest factors of support towards Russia among Serbia's general population. These claims are backed by an independent survey of public opinion in Serbia done in the summer of 2019, which found that there were $60,7 \%$ of Serbian citizens who were in favor of an alliance with Russia, while $47,1 \%$ were supportive of joining the EU, and only $8,9 \%$ supported joining the NATO alliance ${ }^{1}$.

Further adding to the aspect of historical ties between Serbia and Russia, there is great potential in developing Russia's influence through the shared experience of both world wars. It is important to note that Russia and Serbia have been allies in both world wars, and the Serbian nation as a whole views Russian actions in these conflicts as highly positive. While revisionist tendencies in regards to Russia's role in the Second World War are highly noticeable, even the European Parliament openly accused the USSR of having a hand in starting the World War $\mathrm{II}^{3}$, such notions are unpopular in Serbia's political discourse. Russian diplomacy is already achieving certain successes in this field through the organization of "Immortal Regiment" marches ${ }^{4}$. Such marches attract a great amount of attention in

\footnotetext{
${ }^{1}$ NSPM Public Opinion Poll, Autumn of 2019. URL: http://www.nspm.rs/istrazivanja-javnogmnjenja/srbija-jesen-2019.-igre-prestola-i-bojkota.html (accessed: 28.02.2020).

${ }^{3}$ European Parliament resolution on the 80th anniversary of the start of the Second World War and the importance of European remembrance for the future of Europe. URL: https://www.europarl.europa.eu/ doceo/document/B-9-2019-0098_EN.html (accessed: 28.02.2020).

${ }^{4}$ In 2019 «Immortal Regiment" marches in Serbia were introduced as an official celebration of Victory Day on $9^{\text {th }}$ of May, and they received formal state backing. Such marches were organized in many regional towns in Serbia and neighboring Bosnian province of Republic of Srpska.
} 
Serbia amongst the population and the leading media. They are held parallelly with the ones in Russia on Victory Day, on the $9^{\text {th }}$ of May each year.

It is worth nothing that the First World War plays a crucial role in Serbian collective memory. This is namely because the Second World War saw the elevenday collapse of the Kingdom of Yugoslavia, and a bloody civil war that ensued between the monarchists, the communists, and the various national separatist movements. Just as the First World War is easily forgotten in Russia for the same reasons, such is the case in Serbia with the Second World War. Thus, concluding the analysis of historical ties between Serbia and Russia in light of Russia's soft power, it is advisable that Russia develops historical and cultural projects in Serbia similar to the "Immortal Regiment", only with the emphasis on the First World War and the great aid that Serbia received from Russia at the time. This will also connect Serbia's and Russia's history prior to the February and October revolutions, which is in the Serbian collective memory often indiscriminately considered the golden era.

The short conclusion for Russia's soft power in Serbia concerning the aspect of historical ties is that the Russian Federation is highly active in this aspect and needs only to add certain desirable content to it's already successful policies.

In regards to the cultural ties it was already mentioned that the majority of Serbia's population as well as the majority of Russia's population share the same religious faith. Serbian and Russian nation also speak Slavic languages, which are for the most part intelligible (according to some studies Russian and Serbian are $40 \%$ intelligible ${ }^{5}$ ). Having common collective identities makes sharing Russian influence and soft power in Serbia much easier. The Serbian language uses both Cyrillic and Latin alphabets however, opening the gateway to Western influence as well. As both Serbian and Russian nations are based upon cultural ties between individuals, sharing a mutual Slavic identity is an important part of Russia's soft power in Serbia and other Slavic Balkan countries.

While we do not claim that countries that do not share mutual cultural ties necessarily have a lesser chance of spreading soft power (for example Japanese or South Korean soft power spread in countries they have zero cultural ties to), we may put forward a following clarification: soft power is spread more easily if strong cultural ties exist between the two countries, also soft power is hampered if weak cultural ties exist.

Educational ties between Russia and Serbia are getting stronger, but a significantly larger number of Serbian students attend Western universities than they do Russian (there are approximately 400 Serbian students in Russia, while there are around 2000 Serbian students in Germany alone ${ }^{6}$ ). The Russian

\footnotetext{
${ }^{5}$ Lindsay R. Mutual Intelligibility of Languages in the Slavic Family. URL: https://www.academia.edu/ 4080349/Mutual_Intelligibility_of_Languages_in_the_Slavic_Family (accessed: 28.02.2020).

${ }^{6}$ Organization of Serbian Students Abroad (OSSI). URL: https://www.ossi.rs/index.php (accessed: 28.02.2020).
} 
government has several ongoing projects for attracting Serbian students, but they are all centralized through the Rossotrudnichestvo office in Belgrade. This kind of system makes it hard to properly present the advantages of studying in Russia such as the opportunity to study in prestigious universities in a wide array of scientific areas (for example, there is by far more competition to receive a scholarship from a prestigious German university of the same level). There are several reasons why the Western universities are more attractive than Russian and some of them are not connected with soft power at all, such as: better job opportunities in highly developed Western countries, better standard of living while studying, better facilities for academic work.

On the other hand, Russia can make it's educational system more attractive for Serbian students. That is possible by changing the structure of representation of studying in Russia. Instead of highly centralized cultural centers tied to one ministry, Russia should start to develop a network of non-governmental organizations with the aim to provide Serbian students a chance for internship, and even job opportunities in the long-term perspective. This, of course, demands more investment on the side of the Russian government, but this approach has brought great success to Germany, with it's own NGO network tied to different political parties. All of these German NGOs serve as actual recruitment centers for the best and most active Serbian students. This also proves that it needn't be the Russian state that has to be directly involved in financing these NGOs, it can also be the private sector.

The short conclusion for Russia's soft power in Serbia concerning the aspect of cultural ties is that the Russian Federation is mediocrely active and needs to restructure and expand it's approach.

With regards to media and communications, Russian influence practically seized to exist in the Balkans until the previous decade. There were no Russian media in Serbia, except for the radio program The Voice of Russia. There was a correspondent's office of the state-owned media agency ITAR TASS, that to this day operates on a skeleton crew. Before it's restructuring, another state-owned Russian media agency also employed regular correspondents in Belgrade - the Russian Information Agency (RIA).

In 2015 The Voice of Russia and RIA discontinued their activities in Serbia in favor of a new Russian state-owned media Sputnik. The Sputnik is not just a radio station, this media outlet also runs it's own website with news and analytical content, and frequently hosts live streaming programs on YouTube. In February 2020 Sputnik celebrated five years of work in Serbia. President of Serbia Aleksandar Vucic, as well as the minister of foreign relations Ivica Dacic, attended the ceremony. President Vucic even went as far to say that "Sputnik has become one of the most influential media outlets in Serbia today"7, which is a testament not only to this particular media, but to the importance of close ties between Serbia and Russia.

\footnotetext{
${ }^{7}$ Five Years of Sputnik in Serbia. URL: http://www.politika.rs/sr/clanak/447726/Pet-godinaSputnjika-u-Srbiji (accessed: 28.02.2020).
} 
In comparison to Western privately or state-owned media in Serbia, Russian investments in this area is miniscule. However, just because the Western media outlets are widespread to such an extent, makes the much smaller Russian media outlet look as an alternative source of information. This factor, taken together with a high degree of positive sentiments towards Russia among Serbia's general population, makes low-funded Russian media much more popular then analysts would conclude judging by the numbers alone. Sputnik is also rather popular in neighboring countries with a large portion of Serbian population, namely Montenegro and Bosnia and Herzegovina.

The short conclusion for Russia's soft power in Serbia concerning the aspect of media and communications is that the Russian Federation is highly active (taking into account the small investment it has made).

Economic ties between Russia and Serbia are strong because of the free trade agreement between these two countries. Russia is the third partner of Serbia in regards to import of goods and the fifth in regards to export of goods abroad ${ }^{8}$. The biggest trading partner of Serbia is the EU, which takes up $62,7 \%$ of the total yearly goods exchange.

In 2019 Russia exported 1.3 billion euros worth of goods to Serbia, which is just a tiny fraction of Russia's total export gains. Nevertheless, Serbia is an important trade partner of the Russian Federation because of it's geographical position especially in regards to energy resources trade. The current Turkish Stream pipeline project also includes Bulgaria and Serbia as countries through which the gas is to flow into central Europe. The previous project South Stream pipeline failed because the Bulgarian government succumbed to pressure from the United States and the EU.

The Bulgarian and Serbian authorities renamed this prospected pipeline extension the Balkan Stream, because the term Turkish has negative connotations. Whether or not the Bulgarian side will honor it's promises is not a closed matter, but the Serbian government has shown great interest in this project thus far.

In 2008, Russia's Gazprom Neft, a subsidiary of Gazprom, took a controlling stake in Serbia's Naftna Industrija Srbije (NIS) oil and gas company, a deal worth over 450 million US dollars, and committed to invest at least another 600 million dollars in the company. NIS has retained its brand and partially it's management structure, as Serbian government keeps hold of it's minority shares. Year after year NIS is the biggest taxpayer in the Serbian budget, reaching up to $13 \%$ of the budget income in total $^{9}$.

\footnotetext{
${ }^{8}$ The Overall External Trade in the Republic of Serbia for the Period January-August 2019. URL: https://www.stat.gov.rs/sr-Latn/vesti/20190930-spoljnotrgovinska-robna-razmena-avgust-2019 (accessed: 28.02.2020).

${ }^{9}$ Who are the Biggest Contributors to Serbia's Budget? URL: https://www.b92.net/biz/vesti/ srbija.php?yyyy=2014\&mm=01\&dd=16\&nav_id=800601 (accessed: 28.02 .2020$)$.
} 
Serbia's agriculture industry also depends on the Russian market, this is the main reason, besides political ones, that kept Serbia from joining the Western countries in imposing sanctions against Russia. Close to $15 \%$ of all agricultural exports of Serbia are exported to Russia. This may not seem that important, but the majority of the remaining export goes to neighboring countries which means that those goods are exported at a lower price than those that go to Russia. Furthermore, some particular branches of Serbian agricultural production are dependent on Russia, such as the production of raspberry, produced throughout the already impoverished western Serbia.

Russia has also invested in other sectors across the region: banking, retail, real estate, and tourism. In 2012, Russia's state-owned Sberbank purchased Volksbank International, formerly the Eastern European subsidiary of an Austrian banking group, now called Sberbank Europe. The acquisition gave the Russian bank a relatively large retail and commercial banking presence in Southeastern Europe, with assets in Bosnia, Croatia, the Czech Republic, Hungary, Serbia, Slovakia, and Slovenia.

Russia also makes up the greatest number of European tourists in Serbia, surpassing Germany (not counting the neighboring countries in which many Serbians who have relatives in Serbia live $)^{10}$. While Russia's economic influence over Serbia is important it is nothing compared to the influence that the EU fields in this area (especially Germany). There is little that Russia itself can do to remedy this. Russia is a free market economy and private investors make decisions as to where to invest their capital. Clearly, at this juncture Russia has no real interest to more actively engage in investments in Serbia and the Balkans, outside of major pipeline and infrastructural projects it is already involved in. Global instability, trade wars between the US and China, civil war in Ukraine, and involvement in wars in Syria and Libya have stretched the Russian economy to the breaking point.

The short conclusion for Russia's soft power in Serbia concerning the aspect of economic ties is that the Russian Federation is lowly active, but even that activity is enough to exert a certain amount of pressure on the Serbian government.

In summary, Russia can do a lot more in the field of historical and cultural ties to Serbia in order to improve it's soft power and expand it's influence in the aforementioned country. These are fields which do not need large amounts of capital to be invested in order to produce a desirable effect. All that is necessary is the political will and some creative thinking. Russia should definitely stop to rely too much upon it's diplomatic mission and official institutions, and start to spread it's influence in Serbia's civil sector.

10 Serbia's Tourism Income Amounts to 1,2 Billion Euros. URL: https://www.danas.rs/ ekonomija/prihod-od-turizma-12-milijarde-evra/ (accessed: 28.02.2020). 


\section{Perspectives of Russia's soft power in Montenegro}

Historical ties between Montenegro and Russia share a common start in the Middle Ages, as Montenegro was then a part of medieval Serbian kingdom. After Serbia was conquered by the Ottomans in the $15^{\text {th }}$ century the province of Montenegro became independent, but was ultimately also taken by the Ottomans. However, by the $17^{\text {th }}$ century a small mountainous region of Montenegro around the town of Cetinje became independent of Ottoman rule and quickly sought to establish ties with Russia, as the Russian Empire was the protector of Orthodox Christendom at the time. Russia sent aid to Montenegro throughout the centuries and this made the Montenegrin Serbian population one of the most Russophilic in the Balkans.

Today, however, Montenegro is a deeply divided society, with $45 \%$ percent of citizens claiming to be ethnic Montenegrins, and another 30\% declaring themselves Serbs ${ }^{11}$. This divide is even more complicated by the fact that $43 \%$ of citizens of Montenegro claim that the Serbian language is their mother tongue and $37 \%$ declared in favor of the Montenegrin language, while linguistically these languages constitute a single language without a doubt. There is also a question of a schism in the orthodox church of Montenegro, but as recent massive protests led by the Serbian Orthodox Church have shown, the noncanonical Montenegrin Orthodox Church has very little support outside the town of Cetinje, the stronghold of contemporary Montenegrin nationalism. It would be an oversimplification to claim that those Montenegrins who declare themselves as Serbian support Russia, and those who define themselves as ethnic Montenegrins do not. Some public opinion polls in Montenegro are available but they are done by an NGO called CEDEM in short, which is a branch of the Open Society Foundation run by George Soros.

CEDEM's opinion poll from December of 2019 shows that 26,4\% of citizens of Montenegro believe that their country should seek support in matters of foreign policy from the EU, $19,1 \%$ form the US, and $17,4 \%$ from Russia ${ }^{12}$. The same poll found that 55\% of Montenegrins are in favor of joining the EU, while only $38 \%$ percent were in favor of NATO, with $42 \%$ against this Alliance. Nevertheless, Montenegro became a member of NATO in 2017. These numbers show that Montenegrins are mostly in favor of the EU, but are divided in their support to the US and Russia, and while we may doubt these figures coming from a biased source, it is an undeniable fact that the Montenegrin society is a deeply divided one and that does not bode well for Russia's soft power in said country.

11 Montenegro Statistical Agency Report on the 2011 Population Census. URL: https://www.monstat.org/userfiles/file/popis2011/saopstenje/saopstenje(1).pdf (accessed: 29.02.2020).

12 CEDEM Public Opinion Poll, December 2019. URL: https://www.cedem.me/ images/Politicko_javno_mnjenje_decembar_2019pdf.pdf (accessed: 29.02.2020). 
The problem of spreading soft power in Montenegro in Russia is in the extremely antagonistic attitude of the Montenegrin government toward the policies of the Russian Federation. If we analyze the discourse of political leaders from the Balkans it will become clear that most Russophobic statements come from Montenegro, a country whose population is clearly not outright Russophobic. There is little that Russia can do to enhance this relationship soft power wise, as this attitude of the Montenegrin government is tied with the support of Western governments to the regime of president Milo Djukanovic himself. He has been in power for around 30 years and shows no sign of relinquishing power.

In order to skip repetition of presented material, everything that has been said about the historical and cultural ties between Serbia and Russia, also stands for Russia and Montenegro. Russian educational policy in Montenegro is the same as in Serbia - centralized. The Montenegrin experience of world wars is very similar to the Serbian one. The only difference is that Russia cannot organize any public events in Montenegro because Montenegrin officials won't allow it. As far as Russian media presence is concerned, it has already been mentioned that Sputnik in Serbian is the official media center of Russia in the region. That means that Montenegrins can also follow this program.

The short conclusion for Russia's soft power in Montenegro concerning the aspects of historical and cultural ties, as well as media and communications is that the Russian Federation is highly active but it's actions are hampered by the animosity of the current Montenegrin regime towards the Russian government.

The one area that Serbia and Montenegro greatly differ, in regards to perspectives of Russia's soft power, is the aspect of economic ties. Montenegro relies mostly on income it receives from tourism, being a small country without many resources, but with sea access. Montenegro earned around 1,1 billion euros from tourism in 2019, and the most numerous tourists came from Russia, Germany and Serbia $^{13}$. Despite this clear dependency from Russia, Montenegro was one of the first Balkan states outside the EU to impose sanctions on Russia, it did not however impose visas on Russian citizens. Besides the now defunct aluminum combine in the city of Podgorica owned by the CEAC company that is itself a part En+ Group, tied to Oleg Deripaska, Montenegro has no real connections to the Russian economy besides the flow of tourists. If Russia would impose a flight ban to Montenegro because it feared for the safety of it's citizens because of the Russophobic atmosphere created by the Montenegrin government, like it did in Georgia in 2019, this will undoubtably greatly destabilize Montenegro. However, such coercive methods (which are considered hard power) would hurt Russia's soft power in the country, and that may be one of the reasons the Russian Federation still has not used it. Other reasons might be that some Russian businessmen still

\footnotetext{
${ }^{13}$ Montenegro's Tourist Flow Amounts to 26,4 Million Tourist Visits per Year. URL: https://www.bankar.me/2020/02/26/crnu-goru-prosle-godine-posjetilo-264-miliona-turista/ (accessed: 29.02.2020).
} 
keep ties with the Montenegrin government and are active stakeholders in the country, but this goes beyond scientific discourse and into the realm of speculation. On the other hand, Russia clearly has no means of converting it's strong economic ties with Montenegro into soft power, not with the current regime in power in Montenegro.

The short conclusion for Russia's soft power in Montenegro concerning the aspect of economic ties is that the Russian Federation is highly active, but even that activity is not enough to exert pressure on the Montenegrin government without resulting to hard power.

In summary, while the citizens of Montenegro are generally not Russophobic, the Montenegrin government certainly is, and this blocks Russia from expanding it's soft power and influence in the country, at least on the official level. Perhaps it is wise on part of the Russian Federation to restrain itself from using economic hard power, because that would hurt it's relationship with ordinary Montenegrins in decades to come.

\section{Perspectives of Russia's soft power in Bosnia and Herzegovina (BiH)}

Bosnia is a deeply divided society, both in terms of religion and administration. Around half of Bosnia's territory is under the control of the Serbian nation this part is called the Republic of Srpska. The other half is the Muslim and Croat Federation. Maintaining soft power in Bosnia and Herzegovina as a whole is neatly impossible for any country, since $\mathrm{BiH}$ is divided along ethnic and religious lines. If one country supports Bosnia's Slavic Muslim population (the Bosniaks) it's relations with the Orthodox Serbs and Catholic Croats in Bosnia will suffer. The same is true for any of the combinations one might think of. Historically speaking, Russia has been a supporter of the Orthodox population in Bosnia, beginning from the second half of the $19^{\text {th }}$ century up to the present day. This means that Russian influence is seen with great mistrust from the Bosnian Muslims, who see Russia as protectors of Serbs in Bosnia. It is no wonder that Bosniaks consider the United States and Turkey to be their greatest allies, while Serbs think the same of Russia, and Bosnian Croats of Germany. Such is the historical divide of $\mathrm{BiH}$ and even today it seems impossible to overcome it.

The latest diplomatic support from Russia to the Serbian part of $\mathrm{BiH}$ came in a form of vetoing the Srebrenica resolution in the Security Council of the UN in $2015^{14}$. The Srebrenica narrative is extremely important to both the Bosniaks and the Serbs, while the Bosnian Croats are not affected by it. The Bosniaks, supported by the Western countries and the Hague Tribunal, support the version that presents the Srebrenica massacre of 1995 as a local form of genocide. The official Serbian side in the Republic of Srpska supports the version that the Srebrenica

\footnotetext{
${ }^{14}$ Russia vetoes Srebrenica Genocide Resolution at UN. URL: https://www.theguardian.com/ world/2015/jul/08/russia-vetoes-srebrenica-genocide-resolution-un (accessed: 01.02.2020).
} 
massacre was a war crime but not genocide. Whichever country wants to spread soft power in $\mathrm{BiH}$ must first declare which narrative it supports and it's choice will determine from which nation of $\mathrm{BiH}$ it will gain support or disdain from. Russia has clearly chosen to support the Serbian narrative and thusly enjoys a great deal of support from it. It would not be an exaggeration to claim that Bosnian Serbs are more Russophilic than Serbs from Serbia. It is therefore easy to understand why the Bosniaks view Russia's soft power and influence in their country with suspicion.

For Russia to have any chance to work with both sides of the aisle it can develop a two-pronged approach - it can use cultural diplomacy both with the Orthodox and the Muslim population of Bosnia separately. Since Russia is a country with longstanding traditions not only in the Orthodox world but in the Muslim world as well. Why couldn't Russia employ a special envoy to the Muslim part of Bosnia from Tatarstan, for example, in order to demonstrate to the Bosniaks that Russia also has cultural ties with them. This can also be done on an unofficial level using the Islamic communities in Russia to establish ties to their counterparts in Bosnia. Such strong ties already exist between the Serbian and Russian Orthodox churches in the Republic of Srpska. One other focal point of Russia's soft power in Bosnia can be the common heritage of the Second World War. While the Serbian side was divided along ideological lines during the conflict, but fought against the occupation, the majority of Bosnian Croats supported the creation of a proGerman Independent State of Croatia. The Bosnian Muslims were divided and some of them joined the Croats, while the others joined the pro-Yugoslavian communist resistance movement. Since the majority of Serbs also belonged to the communist movement (the Partisan movement was comprised $80 \%$ of Serbs), commemorating the Second World War could became a small bridge that connects these divided nations, and Russia can be the connector. This would reap great benefits for Russia in terms of soft power, and the Russian Federation would demonstrate it's support for reconciliation in Bosnia.

Everything that has been said for Serbia and Montenegro in terms of Russia's educational and media policy stands for $\mathrm{BiH}$, please refer to the section of the article that deals with Serbia.

The short conclusion for Russia's soft power in Bosnia concerning the aspects of historical and cultural ties, as well as media and communications is that the Russian Federation is highly active but only along the existing ethnic and religious divide. This makes it impossible for Russia to expand it's soft power to all of Bosnia and Herzegovina, and not just the Serbian dominated part.

Turning to the issues of Bosnia's economy it must be stated that it is one of the poorest and underdeveloped countries in the Balkans. Most of the Russian investment projects are located in the Republic of Srpska. Investments there have made Russia the fifth-largest investor in Bosnia. Zarubezhneft controls oil refineries in the Republic of Srpska towns of Brod and Modriča, Russia's largest realized investment in Bosnia. It is clear that Republic of Srpska enjoys great economic support from Russia, which is a straightforward sign of Russian strategy of supporting the Serbian side in Bosnia. 


\section{Conclusion}

There are sever general conclusions that can be drawn from the data presented in the article. The first conclusion is that Russia has to diversify it's approach to achieving soft power in the Western Balkans. While the Balkan states share many similarities, there are crucial differences between them as to how they perceive Russia and how much influence Russia can exert on them. The second conclusion is that Russia should abandon it's centralized approach to spreading soft power in the Western Balkans and involve civil society and the private sector in it's strategy. The third conclusion is that Russia should also utilize it's Muslim heritage besides the Orthodox Christian one, especially when trying to win the hearts and minds of Balkan's Muslim population. The fourth and final conclusion is that Russia should not limit it's soft power only to the shared experiences of the Second World War, however important they may be. Russia must use it's long history with the Western Balkans to it's advantage.

Although the EU and the US have for the past three decades remained the dominant forces in the Balkans, both in terms of soft power and hard power, Russia has made great progress in recent years, and it's influence continues to grow and spread. With that said, Russian soft power in the Western Balkans is nearing it's limit, unless more financial means are invested and new strategies of spreading soft power are implemented.

\section{References}

[1] Nye J.S. Soft Power - The Means to Success in Worlds Politics. New York: Public Affairs. 2004: 191.

[2] Bially Mattern, J. The Concept of Power and the (Un)discipline of International Relations. The Oxford Handbook of International Relations. 2008: 691-698. DOI: 10.1093/oxfordhb/9780199219322.003.0040

[3] Kratochwil F., The Monologue of "Science". International Studies Review. 2003; 5: 124128. DOI: 10.1111/1521-9488.501019_2

[4] Campbell D. Why fight: humanitarianism, principles, and post-structuralism. Millennium: Journal of International Studies, 1998; 27: 497-521. DOI: 10.1177/03058298980270031001

[5] Wight M. Power Politics. London: The Royal Institute of International Affairs. 2004: 316.

[6] Bechev D. Russia's Strategic Interests and Tools of Influence in the Western Balkans. NATO Strategic Communications Centre of Excellence. 2019: 34.

[7] Kovic M. Disraeli and the Eastern Question. Belgrade: Clio. 2018: 509 (In Serbian).

\section{Информация об авторе:}

Джокич Александар - магистр политических наук, ассистент кафедры сравнительной политологии Российского университета дружбы народов (ORCID ID: 0000-0003-1897-5642) (e-mail: dzhokich_a@pfur.ru).

\section{Information about the author:}

Aleksandar Djokic - Master of Arts in Political Sciences, Lecturer Assistant of the Department of Comparative Politics, Peoples' Friendship University of Russia (RUDN University) (Russian Federation) (ORCID ID: 0000-0003-1897-5642) (e-mail: dzhokich_a@pfur.ru). 